\title{
The Implication of Musharakah Mutanaqisah in Malaysian Islamic Banking Arena: A Perspective on Legal Documentation
}

\author{
Khairul Hafidzi Mohd Subky, Liu Jing Yuan, Muhammad \\ Muzzammil Abdullah, Zhafri Farhan Mokhtar, Ainaz \\ Faizrakhman
}

International Centre for Education in Islamic Finance (INCEIF), The Global University of Islamic Finance, Malaysia

\begin{abstract}
:
This paper observes the implication of Musharakah Mutanaqisah (MM) in the current Malaysian Islamic banking arena. Musharakah Mutanaqisah was previously suggested as a better alternative for Islamic home financing to replace the controversial Bay Bithaman Ajil (BBA). However, till date, almost half of the Malaysian Islamic banks that offer Musharakah Mutanaqisah financing have stopped providing it. Many studies have been done on the theory, Shariah issues, features and usage of Musharakah Mutanaqisah instruments, but there are limited studies conducted on the implementation of Musharakah Mutanaqisah from the viewpoint of the Islamic banks and customers. The objective of this paper is to discuss the implication of Musharakah Mutanaqisah implemented by the Islamic banks in Malaysia, focusing on the context of legal documentations from the perspective of academicians, banks, and customers. The result shows that due to the documentation issues, Islamic banks face higher risks, and there is an increase in the documentation costs for the customers while implementing Musharakah Mutanaqisah. The finding also shed some lights on the Islamic finance industry in Malaysia.
\end{abstract}

Paper Type: Research paper

Keywords: Musharakah Mutanaqisah, Islamic Banking and Finance, Islamic Home Financing Products, Malaysia 


\section{Introduction}

Malaysia has come a long way from introducing its first fully-fledged Islamic banking institution in 1983 to becoming a leading $\$ 65.6$ billion-asset Islamic banking industry in the world (Bank Negara Malaysia, 2016). In those days, Islamic banks had to be innovative in providing financing facilities to keep the customers free from interestbased transactions. This was especially the case with providing sources to meet the population's basic needs, such as house financing. The long run of Islamic mortgages in Malaysia has started in late 1984 when Bank Islam Malaysia Berhad (BIMB) introduced Bay` Bithaman Ajil (BBA) contract for home-financing scheme - the sale on a deferred payment (Smolo and Hassan, 2011). As an alternative to BBA contract, Kuwait Finance House Malaysia Berhad (KFHMB) launched Malaysia's first equity based house financing facility under the Musharakah Mutanaqisah concept in 2006, which is considered to be more Shariah-compliant compared to BBA (Meera and Abdul Razak, 2005) that has been practiced in Malaysia from the beginning and always been under the criticism for its 'Inah (sale and buy back between two parties) factor.

Musharakah Mutanaqisah or Diminishing Musharakah is a partnership contract between two parties where one party's installments will gradually increase his share in the property till the whole ownership. As we will see from the findings that not only small amount of Malaysia's Islamic banks has switched to Musharakah Mutanaqisah following KFH's example, but how later on majority of them dropped the Musharakah Mutanaqisah concept and replaced it with more convenient products in terms of maintenance and legal support such as Commodity Murabahah (CM), Ijarah Muntahiyah bit Tamlik (IMBT) and Istisna'. Musharakah Mutanaqisah concept can also be used for the purpose of venturing in profit-generating business activities. Nevertheless, it was found during the research that Islamic banks still remain reluctant to do investment businesses and execute Musharakah Mutanaqisah contract in property acquisition transactions.

The objective of this paper is to discuss the implication of Musharakah Mutanaqisah implemented by the Islamic banks in Malaysia, focusing on the context of legal documentations from the perspective of academicians, banks, and customers.

The remainder of this paper is organized as follows. Section 2 reviews the literatures related to BBA and MM, followed by Section 3 that presents the methodology employed. Section 4 provides a brief overview of Musharakah Mutanaqisah, and Section 5 discusses the findings with regards to the trend of Malaysian Islamic banks shifting from MM to other home financing products and the implication of MM's implementation in the context of legal documentations. Special references are also made to the practical issues and risks of using MM, as well as its implementation by a Malaysian cooperative called Koperasi Pembiayaan Syariah Angkasa Berhad (KOPSYA). The conclusion of this paper is presented in Section 6. 


\section{Literature Review}

Musharakah Mutanaqisah (MM) is a diminishing partnership concept that comprises three contracts which are Musharakah (partnership), Ijarah (renting) and Bay` (sales) (Abdullah, 2016; Smolo and Hassan, 2011; Yusof et al., 2016). This hybrid contract has been defined by Bank Negara Malaysia (BNM) as "a contract of partnership that allows one (or more) partner(s) to give a right to gradually own his share of the asset to the remaining partners based on agreed terms" (BNM, 2010).

As an equity-based financing, MM has been argued by many academicians, notably by Meera and Abdul Razak (2009) as a better alternative to replace the famous and controversial Bai Bithaman Ajil (BBA) contract, a debt-based financing which was first implemented in Malaysia by Bank Islam Malaysia Berhad (BIMB) after it was founded in 1983. MM is often cited as a fair and efficient Islamic financing (Smolo and Hassan, 2011).

According to Shahwan et al. (2013), the controversial issues surrounding BBA are not due to its definition or conceptual idea itself, but rather a matter of its operation and how it is being practiced by the banking institutions. One critique against BBA is its use of Bay-Al-Inah (buy-back sale), that is forbidden by majority schools of thoughts except by Shafi'is (Smolo and Hassan, 2011). As BBA financing is collateralized, Islamic banks earn more profits with less risk and efforts using BBA mode of finance (Abdullah, 2016; Smolo and Hassan, 2011; Yusof et al., 2016).

There are several issues faced by the Islamic banks in implementing MM, such as the usage of rental rate which is very much affected by location, tax regulations, as well as wear and tear (Meera and Abdul Razak, 2005), in addition to issues related to revaluation of property such as redemption, defaults and termination of contract (Meera and Abdul Razak, 2009). Local Islamic banks in Malaysia also faced the problem with regards to documentation preparation, as there is lack of Shariah lawyers who are experts and understand the MM contract very well (Shahwan et al., 2013).

One major problem faced by MM financing is its double-taxation issue where customers are obliged to pay taxation twice (Smolo and Hassan, 2011). The Malaysian government made several amendments to the financial acts in order to facilitate and promote Shariah compliant financing. The government has introduced Stamp Duty Remission (No.2) Order 2009, which is extended in 2015. The Stamp Duty Remission (No.2) introduced in 2009 allows home buyers using Islamic home financing to have $20 \%$ discount of stamp duty. More recently, the Ministry of Finance introduced Stamp Duty Remission (No.2) Order 2016, exempting home buyers who use Islamic home financing in buying one residential property which has less than RM500,000 market value (Federal Government Gazette, 2016). To a great extent, these acts neutralize the adverse impact of double-stamp duty on home financing.

International Journal of Management and Applied Research, 2017, Vol. 4, No. 1 


\section{Methodology}

This study analyses data collected from multiple sources, including scholarly literature, primary data gathered through interviews conducted face-to-face, email and phone, as well as secondary data obtained from the corporate websites of Malaysian Islamic banks. 11 respondents from various Malaysian Islamic banks, namely Affin Islamic, OCBC Al-Amin, Maybank Islamic and Kuwait Finance House, academic institutions, namely Islamic Banking and Finance Institute Malaysia (IBFIM), International Centre for Education in Islamic Finance (INCEIF) and one cooperative, namely Koperasi Pembiayaan Syariah Angkasa Berhad (KOPSYA) have been interviewed. Among these 11 respondents, four of them were academicians while another seven were banking practitioners. The findings about MM and other Islamic home financing products, as well as their related documentations are then compared amongst them, and further analyzed and evaluated.

\section{Overview of Musharakah Mutanaqisah}

\subsection{Definition}

Musharakah Mutanaqisah is an Islamic contract with a combination of two words, namely "Musharakah" and "Mutanaqisah". The word "Musharakah" is derived from the word "Sharaka" which means joint or partnership, whereas the word "Mutanaqisah" is derived from the word "Naqasa" which means reduce, decrease, or diminish. Musharakah Mutanaqisah (MM) literally means "Diminishing Partnership", and it consists of three contracts which are Musharakah, Ijarah (leasing) and Bay (sale). Accounting and Auditing Organization for Islamic Financial Institutions (AAOIFI) defines the Musharakah Mutanaqisah as a partnership in which one of the partners promise to buy the whole equity share gradually until the title of the equity is completely transferred to him.

Musharakah Mutanaqisah contract is executed in three stages: first, the customer identifies an asset and enters into a Musharakah contract with the bank to co-own the asset under the concept of Shirkat al-Milk (joint ownership), and the percentage of ownership will be decided according to the amount of initial contribution. Second, bank leases the asset to the customer under Ijarah contract. Third, the customer gradually buys back the asset shares of the bank based on pre-agreed tenure of repayment. Therefore, the customer's asset share ratio will increase after every rental payment plus redemption, until the asset is fully owned by customer.

\subsection{Permissibility}

MM is a relatively new concept. Its history can be traced back to 1970s during the first Islamic Banking conference held in 1979 (Bendjilali and Khan, 1995). In 2010, the concept of MM was approved by Accounting and Auditing Organisation for Islamic Financial Institution (AAOIFI). The Shariah Advisory Council (SAC) of Bank Negara Malaysia stated in its 56th meeting held on 6th February 2006/7th Muharram $1427 \mathrm{H}$ that the financing product structured based on Musharakah Mutanaqisah is permissible, as it is a contract recognized in Islamic Muamalat (Bank Negara Malaysia, 2010). 
MM consists of several contracts which are Musharakah (partnership), Ijarah (leasing) and Bay (sale), and the validity of each of these contracts can be found in any sources of Shariah. According to Asian Institute of Finance (2013), it is permissible in Shariah Law to combine more than one contract in one set (Musharakah and Ijarah) without imposing one contract on the other, provided that each contract is permitted on its own.

\subsection{Historical Background}

The earliest discussion of MM can be traced back to 1970s in which Samy Hamoud proposed the concept of musharakah yantahi bi al tamlik in 1974 (cited by Bendjilali and Khan, 1995). In 1979, the mechanism of MM has been approved by the First International Conference on Islamic Banking, which was held in Dubai (Abdullah, 2016; Bendjilali and Khan, 1995; Smolo and Hassan, 2011). Over the past few decades, the concept of MM for house financing has been widely adopted in United States of America, United Kingdom, Sudan, Pakistan and Malaysia (Abdullah, 2016).

In Malaysia, BBA home financing concept was introduced by Bank Islam Malaysia in 1983, and BBA financing has been introduced by other Malaysian Islamic banks since then. However, BBA financing has been criticised by the Islamic finance scholars as it was deemed to be similar with conventional housing loan due to the fixed rate of BBA and the similar computations in the interest-based system (Meera and Abdul Razak, 2005). An alternative to this product is MM, a Shariah compliant financing. SAC in its 56th meeting held on 5th February 2006 resolved that the product of MM is permissible after Islamic Financial institution has submitted a proposal to offer property financing based on the concept of MM (Bank Negara Malaysia, 2010).

According to the chronology of implementation of $\mathrm{MM}$ in Malaysia, the first institution that implemented MM was a cooperative, namely Koperasi Belia Islam (KBI) Malaysia Berhad under International Islamic University of Malaysia (IIUM) for the house project on 1st January 1989. In Malaysian Islamic banking arena, Kuwait Finance House Malaysia Berhad (KFHMB) was the first Islamic bank that offered home financing products based on Musharakah Mutanaqisah contract in 2006. To date, there are six finance institutions that offer home financing based on MM contracts, these are: Citibank, RHB Islamic Bank (RHBIB), HSBC Amanah, Affin Islamic Bank (AIB), Standard Chartered Saadiq (SCS) and Public Islamic Bank (PIB).

\section{Findings and Discussions}

\subsection{Islamic Home Financing Products Offered by Malaysian Islamic Banks}

Currently, there are 16 licensed Islamic banks in Malaysia (BNM, last updated: 7 October 2015). With regards to home financing, there are five main products offered by Islamic banks in Malaysia, namely Bay Bithaman Ajil (BBA), Musharakah Mutanaqisah (MM), Ijarah Muntahiyah bit Tamlik (IMBT), Commodity Murabahah (CM) and Istisna'.

International Journal of Management and Applied Research, 2017, Vol. 4, No. 1 
BBA is a type of sale where the bank buys an asset from the customer and sells it back to the customer at a deferred premium price. IMBT is a product similar to MM but without the partnership concept. Tawarruq is a transaction for customers to obtain financing by buying an asset from the bank at deferred premium price and sell it in the market at spot price. Istisna' is a contract of sale for agreed specifications of property between the parties with an obligation for the manufacturer to deliver them upon completion to the customer. These home financing products which have been offered by Malaysian Islamic banks are summarised in Table 1.

The information regarding current Islamic home financing products offered by the Islamic banks (Table 1) are obtained through the banks' websites, and only valid as at this time of research. However, the main limitation of this is if a particular bank does not update its website with regards to the particular product. For example, Maybank's website showed that the bank still offer home financing product called HomeEquity-i, a home financing based on MM's concept. During our interview, the respondent from Maybank Islamic said that the bank stopped offering MM for home financing around early 2014. As for the information about the products previously offered but currently stopped by the Islamic banks, they are compiled from various sources such as from our interviews, past literatures, news and the banks' websites.

Table 1: List of Home Financing Products Offered by Malaysian Islamic Banks as of July 2016

\begin{tabular}{clccccc}
\hline No & Islamic Bank's Name & BBA & MM & IMBT & CM & Istisna' \\
\hline 1 & Affin Islamic Bank Berhad & $*$ & $\checkmark$ & & $\checkmark$ & \\
2 & Al Rajhi Banking \& Investment Corporation & $\checkmark$ & & & & \\
& (Malaysia) Berhad & & & & & \\
3 & Alliance Islamic Bank Berhad & $*$ & $*$ & & $\checkmark$ & \\
4 & AmBank Islamic Berhad & & $*$ & & $\checkmark$ & $\checkmark$ \\
5 & Asian Finance Bank Berhad & $*$ & & & $\checkmark$ & \\
6 & Bank Islam Malaysia Berhad & $*$ & $*$ & & $\checkmark$ & $\checkmark$ \\
7 & Bank Muamalat Malaysia Berhad & $*$ & & $*$ & $\checkmark$ & \\
8 & CIMB Islamic Bank Berhad & & $\checkmark$ & & & \\
9 & HSBC Amanah Malaysia Berhad & $*$ & & & $\checkmark$ & \\
10 & Hong Leong Islamic Bank Berhad & & $*$ & $\checkmark$ & & \\
11 & Kuwait Finance House Malaysia Berhad & & & & & \\
& (KFHMB) & $*$ & $\checkmark+$ & & $\checkmark$ & \\
12 & Maybank Islamic Berhad & & $*$ & $\checkmark$ & & \\
13 & OCBC Al-Amin Bank Berhad & $\checkmark$ & $\checkmark$ & & & \\
14 & Public Islamic Bank Berhad & $*$ & $\checkmark$ & & & \\
15 & RHB Islamic Bank Berhad & & & \\
16 & Standard Chartered Saadiq Berhad & & $\checkmark$ & &
\end{tabular}

Source: Authors' Compilation

\footnotetext{
$\checkmark$ : currently offering the product

* : previously offered the product, but currently stopped offering it

+ : stopped offering the product, but did not update its website
}

Currently, there are only 3 Islamic banks in Malaysia that offer BBA and 6 banks that offer MM as their home financing product. However, there are 6 Islamic banks who discontinued home financing based on MM over the past few years. Instead, these banks offer other financing cotnracts, such as CM, IMBT and Istisna'. 
To sum up, as for the alternatives of MM, there are currently 9 banks offering CM, 3 banks offering IMBT and 2 banks offering Istisna', indicating that CM is more popular than IMBT and Istisna' as a home financing product among Islamic banks in Malaysia. KFH, Maybank and OCBC Al-Amin are among the Islamic banks that offered $\mathrm{MM}$ as their home financing product, but stopped offering it. Our finding from Table 1 indicates that the current trend of Malaysian Islamic banks' home financing products is moving away from BBA and MM, and towards Commodity Murabahah (CM) and Ijarah Muntahiyah bit Tamlik (IMBT).

This finding could be explained by two main reasons; Islamic banks' reluctance to offer profit and loss sharing (PLS) contracts, and flexibility of other alternative home financing products, namely IMBT and CM.

\subsubsection{Islamic Banks' Reluctance to Offer PLS Contracts}

Besides Mudharabah, Musharakah is one of the currently applied Islamic partnerships, which is also categorized under profit and loss sharing (PLS) contracts. Several empirical observations suggest that Islamic banks are reluctant to use PLS contracts for their investments, for example Chong and Liu (2009) who study the Malaysian market and found that only $0.5 \%$ of total financing by Islamic banks is governed by PLS-contracts. Chong and Liu (2009) identified the following issues as possible explainations for such low level of PLS-contracts in Malaysian Islamic finance institutions: the competitve nature of banking sector, the difficulty to implement PLS model, risk-avoidance behaviour of Islamic bankers, as well as the inherent riskiness of PLS model.

In addition to that, Abdul Jalil et al. (2013) argued that the Capital Adequacy Framework for Islamic Banks adopted by BNM in 2012 (which was later updated by BNM on 13 October 2015) is also found to have a negative impact on the Islamic financial institutions (IFIs) if they were to adopt Mudharabah-based and Musharakahbased products, and hence may further discourage them from offering Mudharabahbased and Musharakah-based transactions. Therefore, from the literatures, these are the general reasons that might contribute to the trend of Malaysian Islamic banks moving away from MM, which is a Musharakah-based contract, towards IMBT and $\mathrm{CM}$ for their home financing products.

\subsubsection{Flexibility of Other Home Financing Products}

From our interview, the respondent from OCBC Al-Amin mentioned that there are two main reasons why the bank stopped offering MM as its home financing product; risk related to properties under construction and issues related to assets owned by third party. When MM was implemented, OCBC Al-Amin does not offer the product for properties under construction because if construction abandonment occurs, the bank would need to return back all the advanced rentals it receives from the customer, as there is no beneficial ownership. MM home financing product is also inflexible when dealing with third party ownership of an asset, i.e. the property could only be registered under the name of the customer, which is the first party, but not the other people (for example the customer's wife, husband and children), which are the third 
party. When IMBT was introduced in OCBC Al-Amin, the sales officer found out that IMBT could cater for completed properties as well as properties under construction, and assets' first party as well as third party owners. Since IMBT is more flexible and easier to understand, and its documentations are far less than MM, there was no motivation to continue offering MM, hence the product was stopped by OCBC AlAmin and replaced by IMBT. Since then, the bank's customers who took MM home financing started to convert into IMBT financing. The respondent from Maybank Islamic also mentioned that the bank has stopped offering MM and replaced its home financing with CM due to MM's inflexibility with regards to third party ownership (as previously mentioned) as well as higher documentation costs, which will be elaborated later in this paper.

\subsection{MM: Legal Documentations and Related Issues}

Table 2 below shows the list of standard documents used for home financing products based on BBA, MM, IMBT and CM in the Islamic banks in Malaysia. From Table 2 below, we can see that there is an increase of at least two documents when MM is being implemented by the Islamic banks, namely the Promise (Wa'ad)/Purchase Undertaking and MM Facility agreement. There might be some differences of the abovementioned documents, depending on whether the bank is a full-fledged Islamic bank (FFIB), a foreign bank (FB) or a local Islamic bank (LB). One respondent said that it is the MM facility agreement that makes MM documents thick, as compared to BBA's documents. This increase in the number of documents leads to an increase in the Islamic banks' risk and the documentation cost for the product, which will be discussed below.

Table 2: List of Standard Documents Used for Islamic Home Financing Products in Malaysia

\begin{tabular}{|l|l|l|l|}
\hline \multicolumn{1}{|c|}{ BBA } & \multicolumn{1}{|c|}{ MM } & \multicolumn{1}{c|}{ IMBT } & \multicolumn{1}{c|}{ CM } \\
\hline 1. Letter of Offer (LO) & 1. Promise (Wa'ad)/ & 1. Letter of Offer (LO) & 1. Appointment of the \\
2. Property Purchase & Purchase Undertaking & 2. Property Purchase & Bank as Sales Agent \\
Agreement (PPA) & 2. Letter of Offer (LO) & Agreement (PPA) & (ABSA) \\
3. Property Sale & 3. MM Facility & 3. Ijarah Lease & 2. Offer to Purchase \\
Agreement (PSA) & Agreement & (OTP) \\
4. Legal Charge or & 4. Property Purchase & 4. Guarantee & 3. Tawarruq Master \\
Assignment and Power & Agreement (PPA) & Agreement & Facility Agreement \\
of Attorney & 5. Property Ijarah & 5. Charge (Annexure) & (TMFA) \\
& (Lease) Agreement & Document & 4. Tawarruq Agency \\
& 6. Trust Deed (if & A. Deed of Assignment & Agreement (TAA) \\
& applicable) & & \\
7. Service Agency & Agreement & & \\
\hline
\end{tabular}

Source: Authors' Compilation

\subsubsection{Issue of Wa'ad (Purchase Undertaking)}

In implementing Musharakah Mutanaqisah, BNM gives Islamic Banks choice of whether to execute MM with or without Wa'ad (purchase undertaking). Wa'ad is a deed of promise to be signed by the customer at the initial stage of MM contract. This agreement has two promises: (i) the customer will purchase the bank's shares 
gradually and will agree on all the terms and conditions laid down in the facility agreement (ii) the customer will appoint the bank as a trustee to hold the full ownership of the asset until either the MM agreement is dissolved or the bank recovers full outstanding amounts from the customers in the case of default or other situations. The bank will invoke the customer's purchase undertaking and exercise its right of Wa'ad that was given by the customer. If a customer fails to pay the claimed amount, the bank will use its right as trustee to sell the property (BNM, 2013). Having said that, Islamic banks in Malaysia still choose to implement MM contract with Wa'ad, based on the case study done by Asian Institute of Finance (2013).

\subsubsection{Issue of Enforceability of Wa'ad}

The issues here are whether this promise is legally binding, and whether it is enforceable by the court. The Maliki school of thoughts consider a promise is not legally binding and thus cannot be enforced by court of law (Wisham et al., 2011). Therefore, if wa' ad is legally binding and enforceable, it is no longer a promise but instead, it should be considered as a contract. Having this element included into a partnership contract will be a conflict with the Shariah since keeping a promise is a virtuous act in Islam.

Estoppel in English law is a doctrine that can be used as a defense for the purpose of loss-preventing. More specifically, the doctrine of promissory estoppel allows a party to recover the benefit of a promise made even if a legal contract does not exist. However, the concept of estoppel does not exist in Islamic law of wa'ad (Wisham et al., 2011), which could significantly undermine the effectiveness of wa'ad in Islamic financing.

\subsubsection{Issue of Stipulating Wa'ad During Default}

Under the MM agreement of Islamic banks in Malaysia, the customer need to sign the Wa'ad (Abdul-Razak and Fauziah, 2011) or purchase undertaking, whereby the customer promises to buy back the bank's share of the property under any circumstances. According to Smolo and Hassan (2011: 247): "In case that the customer cannot pay even rent, then the property could be leased to the third party while the profit will be shared between the bank and the customer.". The stipulation and enforcement of Wa'ad goes against the guiding principles of Musharakah (Yusof et al., 2016), as any profit and loss should be shared by all partners unless it was caused by the clear negligence of one partner.

\subsubsection{Issue on Risk Sharing}

Risk sharing is one of the main spirit of Islamic Finance, a partnership contract like MM have the underlying principles of risk, profit and loss sharing. Under MM, one of the risks faced by both customers and banks is abandonment of project, and Islamic banks in Malaysia generally treat abandonment of project as the responsibility of the customer. Under the Wa'ad, it is stated that in the event of incompletion or abandonment during construction, the customer is required to buy the bank's interest or payment of any amount equivalent to the outstanding financing balance, as well as any amount due and payable to the bank. Furthermore, the ownership risk shall be

International Journal of Management and Applied Research, 2017, Vol. 4, No. 1 
borne entirely by the customer, even though the bank jointly owned the property. By conduct, if there is any damage on the property that is not covered by Takaful, the customer should be liable for the damage.

However, in Affin Islamic Product Disclosure Sheet (PDS), there is a clause stating that "If the property cannot be occupied due to construction of the Property is abandoned which cannot be revived, the advance rental as duly paid by the Customer, will be refunded to the Customer in the manner as determined by the Bank". Due to the possibility of abandonment in the case of property construction and its related risk, the respondent from OCBC Al-Amin said that the bank did not offer home financing for houses which are under construction.

\subsection{Documentation Costs}

Based on 4 samples of Product Disclosure Sheets (PDS) (Affin Islamic, AmBank Islamic, Maybank Islamic and RHB Islamic), customers are required to pay all legal fees and incidental expenses related to the facility, which includes the preparation, stamping and registration of any security documents and the lodgment and withdrawal of caveats, as well as the disbursement fees that include registration of charge, land search and bankruptcy charge.

According to a respondent who work an Islamic bank, Bank A does not charge any documentation cost to the customers, nor did it pay any fees to the lawyers. However, all the documentation costs were still borne by the customers, but paid directly to the lawyers. Hence, the arrangement was between the customers and the lawyers.

A respondent from another bank (Bank B) said that the documentation cost that customers need to pay for BBA home financing is approximately $2.5 \%$ to $3 \%$ of the total loan, while the documentation cost for $\mathrm{MM}$ is betwen $4 \%$ and $5 \%$ of the total loan. This shows that there is an increase of at least $1 \%$ for the documentation cost that the customers need to pay as they bank changed their product from BBA to MM. The documentation cost for CM is similar to BBA, which is approximately $2.5 \%-3 \%$. This shows that by changing the product from $\mathrm{MM}$ to $\mathrm{CM}$, the documentation cost decreased by at least $1 \%$ out of the total loan.

\subsection{Impact to the Customers}

According to our findings from the interviews, majority first time customers are indifferent when it comes to choosing any types of financing offered by the Islamic banks; it is fine to them as long as the financing is Islamic. The issues they are concerned with are the profit rate, repayment, tenure, and whether the financing is approved or not. Therefore, from the sales perspective, first time customers don't have any basis of comparison. They won't know if there is an increase in the documentation cost that they need to pay, and the increased documentation cost as mentioned above might not give a big impact because the challenges faced while promoting MM product are the same as other Islamic home financing products. Having said that, non-Muslim customers might compare the products offered by the Islamic banks with the ones offered by the conventional banks, in which higher documentation costs might impact their choices. The respondent from one of these

International Journal of Management and Applied Research, 2017, Vol. 4, No. 1 
banks stated that the sales Key Performance Indicators (KPI) for MM product in the bank has not been achieved during the years it was being offered, unlike the KPI for BBA and IMBT, which indicated otherwise.

From the customer's perspective, one of the respondents has disclosed to us about his experience while enquiring about the Islamic home financing product from two NonMuslim sales representatives from two different Islamic banks. Upon the discussion with both of the sales representatives, our respondent noticed that they have no knowledge on the underlying Islamic principles in the product that they are promoting. In addition, they only stressed on the word 'Halal' (lawful) and the product has been approved by the Shariah Committee of the bank, hence making it Shariah-compliant. This might slightly affect the bank's image if the customers really pay attention to these kind of details, which in general, they most probably don't.

\subsection{Usage of Rental Rate vs Islamic Base Rate (IBR)}

Theoretically, the main advantage of MM compared to BBA is that the rental rate used is flexible and revisable, enabling the banks to structure client's monthly instalments based on the prevailing economic condition (Abdullah, 2016; Smolo and Hassan, 2011; Yusof et al., 2016) and hence solve the problem of the difficulty in estimating cost of funds and long term profit rate under the fixed rate used in BBA. However, in practice, Malaysian Islamic banks use Islamic Base Rate (IBR), effective 2 January 2015 (previously known as Base Financing Rate, BFR) as the base to calculate their effective profit rate of MM financing. Charging the rental payment in accordance to IBR will create an impression of similarity with conventional interest rate.

Despite the controversial issue of IBR/ BFR and interest rate, industry practitioner said that although charging rental rate in MM has its flexibility, there are some practical and operational issues of rental rates. There are many variables that will affect the usage of rental rates such as accounting treatment, area rental rate differences, fluctuations of rental rate, etc. One respondent mentioned that using rental rates will bring accounting problems in terms of matching asset and liability (in the Balance Sheet). Plus, the rental rates are harder to figure out, because different area has different rate. Meera and Abdul Razak (2009) mentioned that tracking rentals can be cumbersome and it imposes additional costs particularly if services of independent valuers are sought, unless there are already national or regional rental indices. Therefore, it is not rational to structure MM financing using rental rate.

In addition to that, Meera and Abdul Razak (2009) finds that generally average rental yields for all categories of houses in Kuala Lumpur for the period 1984 to 2005 are lower than BLR and average lending rate except for condominiums, implying that in practice, MM could only be used for properties with potentially high rental only. As for this reason, KFH initially implemented MM financing only for houses in Klang Valley due to the higher rental rate in that area, according to one of our respondents.

However, extending the proposal of Meera and Abdul Razak $(2005,2009)$ to use some kind of real estate index as a benchmark to price MM, Yusof et al. (2016) proposed a new pricing alternative called Rental Rate Index (RR-I) by incorporating

International Journal of Management and Applied Research, 2017, Vol. 4, No. 1 
the ratio of UK RPI over HPI, and their study provides evidence that the proposed rental rate is fair, equitable, sustainable, resilient to economic vulnerabilities and comparable to the conventional interest rates, without depending on them. Their study is also in line with BNM's recommendation to enhance the MM contracts by considering a rental rate (RR) that is more indicative of the actual rental price while taking into account the competitiveness of the product (BNM, FSPS, 2007).

\subsection{Implementation of MM by Koperasi Pembiayaan Syariah Angkasa Berhad}

Besides the Islamic banks, there is one institution in Malaysia that implements MM, which is Koperasi Pembiayaan Syariah Angkasa Berhad (KOPSYA). With an aim of creating a cooperative that provides Islamic banking business and services in Malaysia, KOPSYA was established by Angkatan Koperasi Kebangsaan Malaysia Berhad (ANGKASA), a cooperative that represents the Malaysia Cooperative Movement nationally and internationally. While all of its members are cooperatives, KOPSYA is monitored and regulated by Malaysia Cooperative Societies Commission (MCC). The advantage of being a cooperation finance house like KOPSYA is its flexibility. For example, in the case of default, KOPSYA is able to give more time for the customers to pay or reduce the monthly payments. KOPSYA is also more flexible compared to the banks as it is able to reduce the shares it owns if the customers pay more, leading to shorter and cheaper repayment with an aim to implement the true MM. As a result, the non-performing loan (NPL) for MM in KOPSYA is only at $0.06 \%$ currently. However, KOPSYA does not open MM financing to the public; they are implementing it only for their cooperative members.

\section{Conclusion}

Based on our research, the implication of MM's implementation by Malaysian Islamic banks is that there is an increase in the legal documentations. Due to the documentation issues, there is an increase in the documentation costs that the customers need to pay and there is also an increase in the risks faced by the Islamic banks in implementing the product. Besides that, in implementing MM, most of the Islamic banks in Malaysia are using IBR even though MM has the flexibility in terms of its rental rate. The permissibility of the Wa'ad (Purchase undertaking) signed by the customers while applying MM financing is still ambiguous even though it has been allowed by BNM. The issues arose from MM have lead the banks to seek for other alternatives. Out of the total of 12 banks that offer MM as their home financing products, 6 of them (50\%) stopped offering MM and switched to CM, IMBT and Istisna'. This finding could be explained by two main reasons; Islamic banks' reluctance to offer profit and loss sharing (PLS) contracts and the flexibility of other alternative home financing products, specifically with regards to properties under construction and third party ownership, which could be catered better by IMBT and CM.

Islamic banks are expected to put in place adequate controls to ensure strong Shariah governance and compliance to Shariah principles for all their products, namely MM. Hence, there is no concern with regards to the increase in the documentations in MM product, as the documentations are in place to ensure compliance to the Shariah 
principles. It is recommended here that Islamic finance institutions ease the process of filling the forms and the legal documentations as much as possible, and focus on improving their customer services by looking into possible collaboration with financial technology companies that could offer end customers a better value proposition in terms of ease of use, cost, speed of service and integration with social media. Also, further research might look into the feasibility of MM implementation by cooperatives in Malaysia in the context of consumer home financing, specifically targeting the low and medium income earners.

\section{References}

1. Abdul Jalil, A. Z., Zainol, Z., Md Dahlan, N. H., Maamor, S., Mohamed Naim, A., Abdul Ghani, A., Md. Hussain, M. N. and Ab Bakar, A. M. F. (2013), Challenges in the Application of Mudharabah and Musharakah Concepts in the Islamic Finance Industry in Malaysia, Kuala Lumpur: International Shari'ah Research Academy for Islamic Finance (ISRA).

2. Abdul-Razak, D. and Fauziah, M. T. (2011), "Consumers' perception on Islamic home financing: Empirical evidences on Bai Bithaman Ajil (BBA) and diminishing partnership (DP) modes of financing in Malaysia", Journal of Islamic Marketing, Vol. 2, No. 2, pp. 165 - 176. https://doi.org/10.1108/17590831111139875

3. Abdullah, A. (2016), "Examining US approvals of Islamic financing products and the Islamic theory of lawful profit", International Journal of Islamic and Middle Eastern Finance and Management, Vol. 9, No. 4, pp. 532 - 550. https://doi.org/10.1108/IMEFM-09-2015-0107

4. Accounting and Auditing Organisation for Islamic Financial Institution (AAOIFI) (2010), "Ch.12: Sharika (Musharaka) and modern corporations", in: Shariah Standards, Bahrain: AAOIFI, pp. 199-230.

5. Asian Institute of Finance (2013), Musharakah Mutanaqisah Home Financing, [Online] availble from:

http://www.aif.org.my/clients/aif_d01/assets/multimediaMS/publication/CaseStudy_Mus harakah.pdf (accessed on 20 July 2016).

6. Bank Negara Malaysia (2007), Financial Stability and Payment Systems (FSPS) Report, [Online] availble from: www.bnm.gov.my/files/publication/fsps/en/2007/cp03_002_whitebox.pdf (accessed on 20 July 2016).

7. Bank Negara Malaysia (2010), Shariah Resolutions in Islamic Finance. Malaysia Deposit Insurance Corporation, [Online] availble from: http://www.bnm.gov.my/microsite/fs/sac/shariah_resolutions_2nd_edition_EN.pdf (accessed on 20 July 2016).

8. Bank Negara Malaysia (2013), Shariah Requirements, Optional Practices and Operational Requirements of Musharakah, [Online] availble from: 
http://www.bnm.gov.my/guidelines/05 shariah/CP Musharakah.pdf (accessed on 20 July 2016).

9. Bendjilali, B. and Khan, T. (1995), Research Paper No. 31: Economics of diminishing Musharakah, Jeddah: Islamic Research and Training Institute [Online] available from: http://ierc.sbu.ac.ir/File.ashx?ID=1518 (accessed on 5 January 2017).

10. Chong, B. S. and Liu, M. H. (2009), "Islamic Banking: Interest-free or Interestbased?", Pacific-Basin Finance Journal, Vol. 17, No. 1, pp. 125-144.

https://doi.org/10.1016/j.pacfin.2007.12.003

11. Federal Government Gazette (2016), Stamp Duty (Remission) (No. 2) Order 2016, [Online] available from: http://www.federalgazette.agc.gov.my/outputp/pua_20161227_P.U.\%20(A)\%203 66.pdf (accessed on 5 January 2017).

12. Meera, A. K. M. and Abdul Razak, D. (2005), "Islamic Home Financing through Musharakah Mutanaqisah and Al-Bay’ Bithaman Ajil Contracts: A Comparative Analysis", Review of Islamic Economics, Vol. 9, No. 2, pp. 5-30.

13. Meera, A. K. M. and Abdul Razak, D. (2009), "Home Financing Through the Musharakah Mutanaqisah Contracts: Some Practical Issues", Islamic Economics, Vol. 22, No. 1, pp. 3-27. https://doi.org/10.4197/islec.22-1.1

14. Shahwan, S., Mohammad, M. O., \& Abdul Rahman, Z. (2013), "Home Financing Pricing Issues in the Bay' Bithaman Ajil (BBA) and Musharakah Mutanaqisah (MMP)", Global Journal Al-Thaqafah, Vol. 3 No. 2, pp. 23-36.

15. Smolo, E. and Hassan, M. (2011), "The Potentials of Musharakah Mutanaqisah for Islamic Housing Finance", International Journal of Islamic and Middle Eastern Finance and Management, Vol. 4, No. 3, pp. 237-258. https://doi.org/10.1108/17538391111166476

16. Wisham, AI.; Muneeza, A. and Hassan, R. (2011), "Special legal features of the Islamic wa'd or pledge: Comparison with the conventional law on promise within the sphere of Islamic finance", International Journal of Law and Management, Vol. 53, No. 3, pp.221 - 234. https://doi.org/10.1108/17542431111133445

17. Yusof, R. B. M., Mahfudz, A. A., Che Mohamed Arif, A. S., \& Ahmad, N. H. (2016), "Rental Index Rate as an Alternative to Interest Rate in Musharakah Mutanaqisah Home Financing: A Simulation Approach", International Journal of Islamic and Middle Eastern Finance and Management, Vol. 9, No. 3, pp. 397416. https://doi.org/10.1108/IMEFM-11-2015-0141 